\title{
Microscopes and corkscrews
}

\author{
Shaun McCann ${ }^{1}$
}

Received: 14 November 2018 / Accepted: 14 November 2018 / Published online: 4 December 2018

(c) Springer Nature Limited 2018

'It reminds me of my safari in Africa. Someone forgot the corkscrew and for several days we had to survive on food and water'.

W.C. Fields. American comedian (1880-1946).

\section{'The microscope is to haematology as the corkscrew} to wine'.

Shaun R. McCann. Haematologist/writer. (1946-)

I suppose it is axiomatic to say that haematology 'came of age' with the use of the microscope and reproducible staining methods. The Romans used the so-called reading stone and Seneca (3 B.C.-65 A.D.), Roman playwright and Stoic philosopher is said to have read all the books available in Rome through it. It seems that the reading stone was little more than a concave glass which magnified the image.

Zaccharias Jannsen and his son Hans in The Netherlands at the end of the 16th century, are credited with inventing the microscope when they discovered that by combining lenses in a tube, the object being scrutinised appeared to be enlarged. It was Anton van Leeuwenhoek (1632-1723), also of The Netherlands, who taught himself new methods for grinding and polishing tiny lenses of great curvature which gave magnifications up to 270 diameters. With his microscopes, he was the first to see and describe bacteria, yeasts and the circulation of blood corpuscles in capillaries [1]. He reported his findings to The Royal Society and the French Academy although his first communication to the former was greeted with mirth and derision.

The immediate forerunner of today's microscope was monocular and had a mirror beneath the stage onto which a light was shone. Microscopes in current use are binocular and may have multiple heads for teaching. The light source

Shaun McCann

shaunrmccann@gmail.com

1 Department of Haematology and Academic Medicine, St James' Hospital and Trinity College, Dublin, Ireland is built in and lenses have an anti-glare coating. Microprocessors are also incorporated into the microscope stand making photomicrography relatively easy. Today, fluorescent microscopes and confocal microscopes are in wide use. The electron microscope (EM) and the scanning EM were widely used in haematology in the 1970s and 1980s but are rarely used diagnostically today.

The unsung hero of microscopy was the French Public Health physician Alfred Donée (1801-1878) who tried hard to interest the medical profession in microscopy. He discovered and identified Trichomonas Vaginalis and provided and financed educational classes in microscopy for doctors in Paris. However, he was largely ignored as he was not a professor at a Paris University [2].

Unfortunately, the art of examining a well-made blood film is waning in spite of the vigorous efforts of a few [3]. A relative contacted me recently as she was told she probably had leukaemia. She had undergone many expensive laboratory and radiographic investigations but when I asked had anybody examined a blood film, the answer was no! I think she probably had infectious mononucleosis! Examination of a well-made blood film is part of the physical examination; it is not only informative but inexpensive. Failure to examine a blood film may lead to misdiagnosis, frustration and the use of many expensive and inappropriate investigations. Likewise, the absence of a corkscrew can make access to a glass of wine a frustrating experience.

Like many of you, no doubt, I have opened numerous bottles of wine since my student days and rarely thought much about corkscrews. Recently, I met Gianfranco Campione who had curated an exhibition of corkscrews in Castellina in Chianti. This made me think more about this vital implement.

As wine drinkers, we all know that wine was originally stored in amphorae, sealed with pieces of wood or cork wrapped in hemp. The Romans introduced barrels for fermentation, transporting and ageing. Glass bottles were introduced in the first century A.D. These bottles were used for serving wine but were fragile, expensive and did'nt hold 


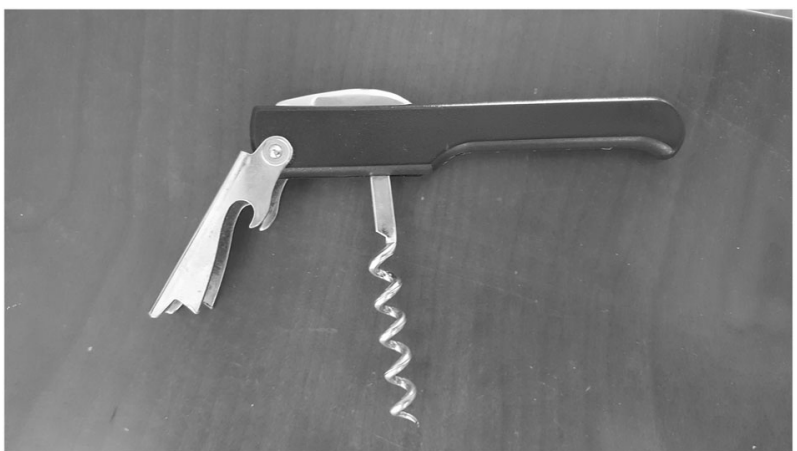

Fig. 1 The waiter's friend

a standard amount of wine. They were often closed with a glass stopper.

The modern age of wine bottles began in the 17th century in England when Kenelm Digby produced wine bottles. The British Parliament officially accredited this invention to him in 1662. The bottles were exported to The Netherlands initially and subsequently to France sealed with cork stoppers. Thus, the introduction of cork stoppers, which made airtight storage possible, became widespread. But it also created a new problem: how to get the corks out of the bottles? The race to produce corkscrews began.

The word corkscrew was not used until 1724. The use of cork was facilitated in Britain by the importation of shiploads of corks from Portugal. Thus, Britain paradoxically became a leading manufacturer of wine bottles, corks and corkscrews in spite of not being a major producer of wine.

Corks can be contaminated with TCA (2,4,6-trichloroanisole) which is a compound formed by interaction of phenols, chlorine and mould and gives wine a 'musty' smell and taste. When this happens, we say that the wine is 'corked'. Blast-freezing of corks, composite corks and plastic 'corks' are now used in some vineyards to eliminate TCA contamination.

Returning to the subject of corkscrews, my preference is for the so-called waiter's friend (Fig. 1). It is simple, inexpensive and rarely lets you down. Many people use the 'butterfly' corkscrew or the 'Fogliano Priveligiato', which originated in Turin but I find it clumsy and unreliable. You can also buy expensive battery-operated corkscrews if you want to impress your friends. If you are really wealthy and only want to drink one glass from your favourite bottle of Château Pétrus 1970, a gadget which might interest you is called Coravin (Fig. 2) [4]. It can be ordered online at www.coravin.com. The system was developed by Greg Lambrecht, a medical device inventor. Apparently, he was developing a needle for multiple punctures, to give and take blood. When his wife became pregnant, he had no one with whom to share a bottle of

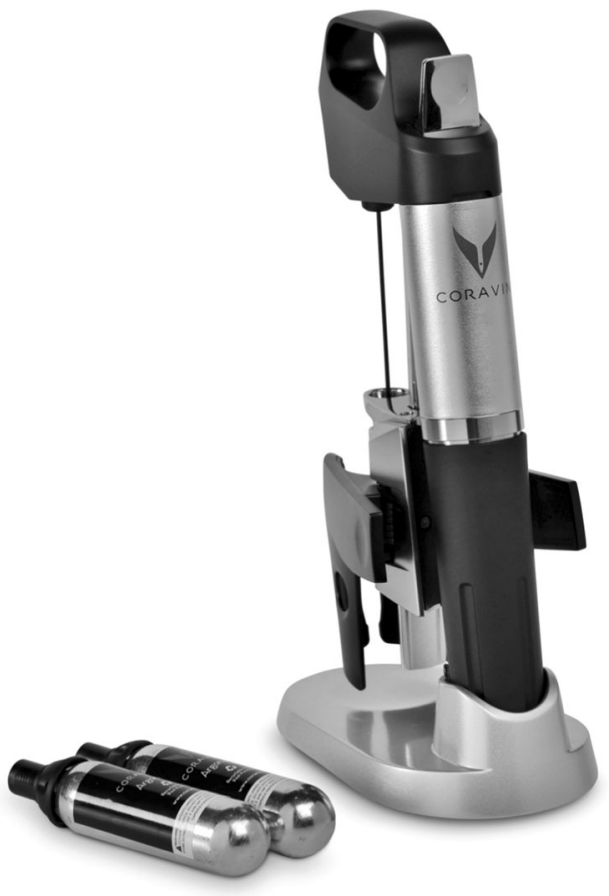

Fig. 2 The Coravin

wine, so he developed the 'Coravin' which works by instilling a narrow needle through the cork into the wine bottle. You pour a glass of wine, instill argon gas to replace the volume, remove the needle and the cork reseals itself. I haven't used the device but it comes highly recommended by the Wine Spectator.

Whatever type of corkscrew you use, always smell the cork after extraction and don't confuse a few bits of cork floating on the wine with a 'corked' wine.

Acknowledgements I am very grateful to Gianfranco Campione for information supplied at the Italian Association of Corkscrew Collectors exhibition in Castellina in Chianti.

\section{Compliance with ethical standards}

Conflict of interest The author declares that he has no conflict of interest.

\section{References}

1. Bynum W. The history of medicine: a very short introduction. UK: Oxford University Press; 2008.

2. McCann SR. A History of Haematology: from Herodotus to HIV. UK: Oxford University Press; 2016.

3. Meyerson HJ, Lazarus HM. Bone marrow structure and diagnostic testing. In: Schmaier AH, Lazarus HM, editors. Concise Guide to Hematology. Oxford: Wiley-Blackwell; 2011. p. 197-219.

4. Morelli G. Uncorking the cheer for Christmas. Irish Medical Times. December 6, 2013. 